\title{
Privatization Versus Public Funding on the Atacama Desert Railway - An Interpretation
}

\author{
Jose Antonio Gonzalez-Pizarro \\ Universidad Católica del Norte, Antofagasta,
}

Chile

\section{Introduction ${ }^{1}$}

Before the arrival of railways at the Atacama desert, there were only paths and tracks inherited by caravans exchanging products - the complimentarity of John Murra's ecological ground - between the Cordillera puna and the Pacific coast. The cart roads of mining prospectors from the time of the manure and copper cycles corresponding to the republican beginnings in the plateau would be added to this pre-Hispanic sequence. But, with the discovery of potassium and silver nitrate in the middle plateau during the 1860s1870s, the multi-ethnic population settlement of Europeans and Latin Americans could be possible, the Chilean one being the most numerous. Human settlement started on the coast; Tocopilla and Mejillones in the 1840s, preceded by Cobija in 1825; then, Antofagasta in 1866. These were seaports prepared for merchandise shipping and traffic to Bolivia. Further south, that is, from parallel 24, settlement occurred in Taltal in 1858 and Paposo small port in 1865. It was the need of connectivity among the productive mining sites of the desert and communication with Potosi from the coast what made it possible to visualize a more modern and efficient means of transport in terms of capacity, speed, and safety: the railway.

As any history of techniques and means of transport, railways fall within a space and time framework connected to the well-known history of the desert geography: a process marked by landmarks, opportunities, and a long-lasting process, to use French historian Fernand Braudel's categories (Braudel, 1970). In this historic context, the Atacama desert railway is the reflection of various aspects of the social, economic, political, and natural resource history of this territory. But, at the same time, the railway together with the telegraph symbolized the keen desire for progress, science potencial, and Comte's positivistic philosophy for contemporary people, as expressed by engineer Matias Rojas-Delgado, the first Antofagasta Mayor in 1872, that is, that science should lead to the rationality of mining work and railways would open the frontiers of the unknown. "Order and Progress" was a motto that triggered private ventures and set the basis for organizing a new society in this place (Gonzalez-Pizarro, 2002). This changed the image that had been inherited from Spanish chroniclers and the first republican travellers. Science and technology that poured on the desert owing to the changes made to the nitrate leaching system thought of in

1This paper is part of Fondecyt Project 1100074 and Nucleo Milenio "Ciencia Regional y Políticas Públicas", 2011. 
England by James Shanks and introduced by Santiago Humberstone in the sodium nitrate industry, along with the demand for locomotives and wagons made in Europe, opened a new positivistic reading of the desert (Gonzalez-Pizarro, 2009).

Geography and scientific knowledge influenced the design of railway communication. We must remember that this geographic knowledge, including its maps, has its landmark in the explorations of Rodolfo A. Philippi, a German scientist hired by the Chilean government to travel in the desert from 1853 to 1854 . His conclusions contained a certain geographic determinism: "it is extremely difficult, not to say impossible, to build railways or electric telegraphs in the desert... the many ravines, 150 to $200 \mathrm{~m}$ deep, that constantly cut through the current road... these ravines would be avoided by a line located further west, but no water would be found in it" (Philippi, 2008: 132). Philippi added that important findings related to mining wealth could change his assumptions. This geographic conditioning of the desert considered the world's most arid remained as a barrier that would demand more accurate topographic studies since it would be affected by the presence of phenomena resulting from the climate, such as camanchaca, the optical illusion that made man be lost in this huge space. The Chilean government sponsored other studies of the desert, in both the middle plateau, as entrusted to the French geographer Pedro A. Pissis, and along the coast to its Navy Captain, Francisco Vidal-Gormaz in the 1870s, before the war. The increase of geographic knowledge became outstanding in Alejandro Bertrand's (Bertrand, 1885) and Francisco San Román's work in the Atacama Desert Exploration Commission (San Román, 1896). The physical description, mapping, mining potentiality studies, and fundamental toponymy of the desert were Bertrand's and San Roman's main contributions.

Thanks to San Roman's effort, scientific work could show that the Atacama desert nomenclature had narrowed regarding the colonial territory. In his work Desierto $\mathbf{y}$ Cordilleras de Atacama (1896), he established a close relation between what was understood as the Atacama desert and what was known from the towns and industries established in the plateau:

"The long stretch of Chilean territory running from the wild valley of Huayco to the nitrate pampas where the Loa river runs, encompassing between both extreme borders in all Chile's width, which extends from the Pacific coast to the Andes crest, is what was properly taken as the Atacama Desert until the beginning of this century. This denomination has been more and more restricted to the north as general progress and mining findings were populated or made exploration in this territory accesible, founding towns and creating industries in them. However, as a mere geographic title and, above all, as significant of an arid zone and production exclusively due to the mineral kingdom, traditions and customs still keep that denomination for all the territory that includes two Chilean provinces today, Atacama and Antofagasta" (San Román, 1896: III-IV).

The geographic knowledge and naming of ravines, mountains, and other territory accidents made it possible to conquer the land. Let's say that the Antofagasta-Bolivia Railway Company (A.B.R.C or F.C.A.B, for its acronym in Spanish) was a reference for Santiago Astronomy Observatory until 1910 to localize parallels $23^{\circ}$ and $24^{\circ}$ south latitude in the Antofagasta province hinterland.

The expansion of the Atacama desert railways shows that they were connected to nitrate findings in 1866 and silver in 1870, when the territory was divided in terms of sovereigneity. 
The Ceasefire Agreement between Chile and Bolivia in 1866 and 1874 moved the border to parallel 24 S latitude: Chile owned the land to the south and Bolivia to the north, as long as we are interested in noting, without putting emphasis on articles regarding custom's rights or the absence of taxes to Chilean nitrate activity during 25 years. This situation would change as a result of the Pacific War, 1879-1883, in which Chile took over the territory in dispute (Lagos-Carmona, 1981; Gonzalez-Pizarro, 2005).

The geographic sector for the main railway activity was the one connecting MejillonesAntofagasta axis to the hinterland, where the main nitrate mines are located (the central or Bolivian canton) with a northeast orientation, that is, the interconnection among Carmen Alto nitrate mine, Salinas station, Caracoles mine - currently located in Sierra Gorda county - and the extension to Calama, where the network was expanded to connect with Bolivia.

The beginning of the railway in this area mixes unsuccesful projects, proposals accepted but not implemented, and outlines that became real. In 1872, the French explorer André Bresson (Bresson, 1997: 180) stated that the railway would change a five-day long and deadly journey from the coast to Potosi by a comfortable five-hour one. Exactly so, the Atacama desert, in being dominated by mining techniques and the introduction of the railway became, from a "naturalistic-deterministic" nature under a colonial perspective, a nature viewed from a "pragmatic-utilitarian" optics (Gonzalez-Pizarro, 2008).

The exploitation of Mejillones manure and Cobija commercial activity stimulated Bolivia to do a public bid to build a railway connecting Cobija and Calama during Jorge Cordoba's administration in 1856. This, along with other projects such as Gibbson's and Arrieta's in September 1863 to build a railway to Mejillones, or Roberto Brown's in August 1868 to build a railway from Cobija to Potosi, were projects discussed in La Paz government, but did not turn out successful. It is important to highlight Avelino Aramayo's project presented in 1861: "Connection of the Pacific Ocean and some point in Bolivia" with Mejillones railway, which would be supported by the government in 1863. Aramayo would get a loan in London by being a partner of Mr. Samuel Morton-Petto-Barnett and Mr. Edward LadolBetts, based on a study of the German engineer Hugo Reck, giving Mejillones manure companies as a guarantee. Avelino Aramayo's partners broke in 1871, the Bolivian government keeping its interest in the route starting in Mejillones. So, they made a bid for this purpose in the same year. Twenty-seven projects were put forward, but none of them was successful, including Gustavo Bordes's and partners' and that of José Manuel Brown, Marcial Martinez, and Enrique Meiggs (Bravo, 2000:53-58). According to Gomez-Zubiela, another Aramayo's project had been passed by the government through a resolution passed on May 22, 1872. This fact would be the obstacle for the "famous railway constructors" appearing during Melgarejo's government, Milbourne Clark and Carlos Watson, among them. The suspension of the railway construction in 1874 affected the whole mining and commercial area (Gomez-Zubiela, 1999; Perez, 1997). It was the time of the great Caracoles silver ore deposit discovery in 1870, so that Mejillones railway could connect this small port to this small place and its mines. However, Aramayo's project sponsored by La Paz government became an obstacle for other projects such as the concession requested by Milbourne Clark \& Co. on January 14, 1873, for a Mejillones-Caracoles railway, or by Felipe Iturriche to connect Cobija and Calama in March 1873 (Gonzalez-Pizarro, 2010: 919).

The big British investments in the nitrate industry, along with the Chilean ones, would influence the de facto orientation of railway policies. Milbourne Clark \& Co., created on March 19, 1869, was funded by Chilean capitals - Jose Santos Ossa, Francisco Puelma, 
Agustin Edwards - and British investments - Milbourne Clark, George Laborer, and Casa Gibbs from Valparaíso. The official negation to Milbourne Clark \& Co. did not prevent it from continuing with its railway project, changing its beginning from Antofagasta to its hinterland. Under the name "Nitrate Company and Antofagasta Railway" established in October 1872, its railway arrives at Salar del Carmen on December 1, 1873; Salinas in 1877; Pampa Central in 1881; and Pampa Alta in 1883. At this time, it was estimated that the railway construction from Antofagasta, the establishment of the big nitrate treatment plant in this port, and manure exhaustion would result in the abandonment of the Mejillones railway (Mandiola \& Castillo, 1894: 3vta). The consequences of the Mejillones-Caracoles railway failure affected its workers negatively due to the high transport costs resulting from operations with the Antofagasta railway company (Bravo, 2000). For Bowman, the future of the Antofagasta port was determined by the railway construction (Bowman, 1924: 81).

\section{The appearance of the Atacama desert railway giant: The Antofagasta and Bolivia Railway Company Ltd.}

The thriving nitrate activity in the Antofagasta province was slowed down at the south of parallel $24^{\circ}$ after the war because of the government tax legislation that favored Tarapaca and affected the economic activities of the zone (Gonzalez-Pizarro, 2009a). At that time, the ideology of political liberalism prevailed in Chile, thus being reflected in economic policies, which would influence concessions to foreign companies.

At the beginning of the 1870s, Huanchaca Company had been established in Bolivia with the participation of Chilean investors, Melchor Concha y Toro, among others and Bolivians such as Aniceto Arce, all of them interested in the exploitation of silver from Pulacayo and Huanchaca. The ceasefire between Chile and Bolivia in 1884 again brought under discussion the mining production export from Huanchaca via Calama to Antofagasta port. Economic interests, mainly in mining, became powerful in outlining new railways.

Blakemore suggests that at the beginning of 1887, the Nitrate Co. and Antofagasta Railway had sold its railway and other rights to Huanchaca Company (Blakemore, 1996: 49). Nevertheless, the first Antofagasta Railway Co. Report shows 1886 as the exact date and gives details about the contribution to the merger between Nitrate Co. and Huanchaca Co., more particularly regarding the amount corresponding to the railway: 2,600,000 pesos distributed in: Permanent Rails: 1,600,000 pesos; Rolling Stock: 740,000 pesos, Antofagasta Machine Shop: 150,000 pesos; Dock: 50,000 pesos; and Antofagasta Real Estate: 60,000 pesos, according to Gomez-Zubiela.

The merger between Antofagasta Nitrate Co. and Huanchaca Co. gave rise to the most important and trascendental railway company of the Atacama desert on November 28, 1888: The Antofagasta and Bolivia Railway Company Ltd. (A.B.R.C), legalized by the Chilean government on April 2, 1889 and the Bolivian Congress on December 8, 1888. The demands of the preandean topography made engineering work essential in order to overcome natural barriers. This was done by the English engineer Josiah Harding who, between 1883 and 1887, lay the rails from Pampa Alta to Ascotan lake, the bridge reaching 3,956 m.a.s.l. It was November 1883. The famous Conchi duct was in operation until 1918, when a similar one was built (Greve, 1944: 507). The newly established town of Uyuni in Bolivia received the first engine from the brand new company on October 30, 1889. The railway extension from Antofagasta to Oruro on May 15, 1892, under Arce's government, also stimulated the modernizing boom process of the 
Bolivian city, together with tin exploitation. It was even stated that civilization was measured in railway kilometers (Mendieta-Parada, 2006: 211). Liberalism years in Bolivia had led to a huge influence of British capitals on the railway network and the connection of the railway with the Pacific Ocean, where "Playa Blanca Metallurgical Installations" was located, connected to Huanchaca Co. built between 1888 and 1892 and in operation until 1902 (Ahumada, 1999; Mitre, 1981; Calderon, 2003). The disappearance of Huanchaca Co. let Antofagasta-Oruro railway under the administration of only the A.B.R.C. in 1903. It is important to note that the arrival of the railway at Calama influenced work usually done by mule packs and alfalfa pasture grounds dedicated to cart transport in the nitrate pampa (Nuñez, 1992).

The prowess of extending the railway from Antofagasta to Bolivia is also shown in the various railway stations that had to be built along its way:

\begin{tabular}{|c|c|c|}
\hline $\begin{array}{l}\text { Km from } \\
\text { Antofagasta }\end{array}$ & Altitude & $\begin{array}{l}\text { RailwayBranches } \\
\text { Stations }\end{array}$ \\
\hline 0 & 34 & Antofagasta \\
\hline 4 & 60 & Playa Blanca \\
\hline 14 & 295 & Sgto.Aldea \\
\hline 21 & 408 & La NegraArranque hacia cantón A. Blancas \\
\hline 29 & 554 & Portezuelo \\
\hline 35 & 561 & $\begin{array}{l}\text { O'HigginsOf.Savona,Pissis y } \\
\text { Domeyko Arranque hacia Boquete. }\end{array}$ \\
\hline 48 & 573 & Uribe \\
\hline 59 & 682 & Prat \\
\hline 70 & 783 & Latorre \\
\hline 83 & 893 & Cuevitas \\
\hline 96 & 1,014 & BaquedanoOf.Ercilla,Astoreca,J.F.Vergara \\
\hline 109 & 1,164 & Cerrillos \\
\hline 117 & 1,231 & El BuitreOf.Sgto.Aldea. \\
\hline 120 & 1,279 & Santa Rosa \\
\hline 122 & 1,285 & Carmen Alto Of.F.Puelma,Condell, Celia \\
\hline 128 & 1,341 & $\begin{array}{l}\text { Salinas Of.Lastenia,Aurelia,Carmela } \\
\text { Blanco Encalada. }\end{array}$ \\
\hline 133 & 1,369 & PeinetaOf.Ausonia, Cecilia \\
\hline 136 & 1,383 & CentralOf.A.Edwards. \\
\hline 144 & 1,414 & $\begin{array}{l}\text { UniónOf.Anita,Candelaria,Luisis } \\
\text { Angamos, Araucana. }\end{array}$ \\
\hline 148 & 1,431 & PlacillaOf.María, Curicó \\
\hline 154 & 1,470 & SolitarioOf.Filomena, Perseverancia \\
\hline 162 & 1,534 & La NoriaOf.Aconcagua \\
\hline 170 & 1,623 & Sierra Gorda Arranque para Caracoles \\
\hline 179 & 1,727 & Cochrane \\
\hline 205 & 2,142 & Cerritos Bayos \\
\hline 238 & 2,265 & CalamaA Chuquicamata y El Abra \\
\hline 269 & 2,641 & Cere \\
\hline 299 & 3,015 & Conchi \\
\hline 312 & 3,223 & San Pedro \\
\hline 340 & 3,772 & Polapi \\
\hline 360 & 3,955 & Ascotán \\
\hline 387 & 3,729 & Cebollar \\
\hline 412 & 3,692 & San Martín \\
\hline 435 & 3,696 & OllagüeA Collahuasi \\
\hline
\end{tabular}


Altitudes referring to railway stations close to the Chile-Bolivia border demanded hiring qualified manpower that attracted Bolivian immigration (Gonzalez-Pizarro, 2008a).

The railway hired many technical and non-technical workers and was not far from the problems between capital and work, proper of political liberalism and the so-called local "social matter". As Blakemore states, A.B.R.C. hired manpower, clearly distinguishing the laborer segment (heads of gang, boatmen, port loaders, firemen, trackwalkers, and service personnel) from employees, who enjoyed a higher social status (railway station chiefs, foremen, inspectors and office personnel) (Blakemore, 1996: 155).

Some specific facts hurt the company's reputation in the regional community. Indeed, there was criticism regarding its operations because wagons used to run off the rails and put workers' safety in risk due to lack of personnel or victimization affecting men who built Pampa Alta railway station telegraph line, as dennounced by the local newspaper La Mañana on October 1, 1902. Although the railway company contributed to the city with the creation of a Fire Department, "Bomba Ferrocarril", in September 1902, its expansion in the province, such as the petition of land in Mejillones at the end of 1903, was criticized in the National Congress. However, when the government asked engineer Emilio de Vidts to study Mejillones opening in 1905, A.B.R.C. started its greatest investment: The construction of Mejillones machine shop, considered South America's greatest one, with a 300-house camp (Panades, 1990)

The most complex social situation affecting The Antofagasta and Bolivia Railway Co. Ltd was the rejection to the petitionary on January 29, 1906, through which the so-called "Mancomunal Obrera de Antofagasta" representing the laborers of the main companies in the city, including the railway, requested one hour and a half for lunch. This request was accepted by all companies, except the English A.B.C.R. administration. The boatmen and Orchard Industry and Smelter workers supported the railway laborers. The strike committee called for a meeting on Febrary 6; while the government sent naval forces and the A.B.R.C administration provided foreigners with guns. Bishop Luis Silva-Lezaeta's eclesiastic mediation was not accepted by the company. The strike ended in a laborers' massacre in Colon Square on February 6, 1906. Two days after, under the pressure of the news, the National Congress passed the first social law: the law of housing for laborers (Gonzalez-Pizarro, 2009b)

The importance of A.B.R.C. in the zone was enormous, particularly when the Peace and Friendship Treaty between Bolivia and Chile was signed in 1904. On the one hand, the treaty stated that the Atacama desert, which was part of the Antofagasta province, would belong to Chile and, on the other hand, Chile would have to build a railway to connect Arica and La Paz, along with allowing free transport from the altiplanic country to Pacific ports. The Antofagasta-Oruro railway perfectly met the requirements stated in the treaty. If, for Bolivia, The Antofagasta and Bolivia Railway Co. Ltd. was so important due to railway policy control, obtaining advantages for mineral exports and mechandise imports (Aramayo, 1959; Gómez Zubiela, 1999, Informe, 1959), what was observed in Antofagasta regional economy was as important. Three issues were controversial for Antofagasta and Calama City Halls and mining companies: water supply and its cost for consumers, real estate valuation, and the price for transporting cargo and passengers.

Water supply in the desert was essential for productive activities and also for the feasibility of the railway company since it used steam engines. The problem was the monopoly concerning water rights and its distribution to the urban cities and insdustries in the nitrate pampa. 
Huanchaca Co. had purchased the water rights owned by Enrique Villegas, an entrepreneur and regional politician, in 1887. For this reason, when Huanchaca Co. transferred its rights to The Antofagasta and Bolivia Railway Co. Ltd., it was not only connected to railway materials, but also to its water rights. In addition, a law passed on January 21, 1888, allowed Huanchaca Co. to "provide the city of Antofagasta and other territories that can be supplied by the Loa River with tap water" (Anguita, 1912: 64-65). Also, Huanchaca could extend the time to do the necessary work for supplying Antofagasta with water. By a law passed on September 23, 1890, the deadline was extended until October 1, 1892. But it was not known that Huanchaca had become The Antofagasta and Bolivia Railway Co. Ltd in 1889. In this way, a situation similar to Tarapaca, concerning John T. North's activities, arose during Balmaceda's government, that is, the direct or indirect monopoly of natural resources, nitrate and water, railway control, or what historian Hernan Ramírez-Necochea would call, the danger of "northification" (Ramirez, 2007: 81). When travelling to Antofagasta in March 1889, Balmaceda visited some railway stations of the central network and promised "the expropriation of all private railways in the whole Republic" (Sagredo, 2001: 144), something probably expressed at the warmth of welcome in every northern City Hall, but these ideas, as many others, did not come true (Blakemore, 1991).

A.B.R.C. tap water supply included industries, nitrate mines at special prices, and the cities of Antofagasta and Calama, among others. The water price and mainly free supply to public services were the focus of a permanent struggle between the company and the Antofagasta City Hall. By a decree on July 30, 1904, the company could "use and enjoy Palpana waters and then obtained the concession of Ujuna Grande, Puquios, and Siloli waters" (Arce: 1930: 263). In addition, it established a policy to fight for free water resources in favor of Antofagasta public services and City Hall (Blakemore, 1996: 104). Antofagasta water supply was criticized because of the tariff charged for houses and the government negation for allowing the company to increase tariffs (Recabarren, 2002). This was a recurrent issue until the late 1960s.

The basic issue for Calama City Hall was the discrepancy between real estate and the valuation established by A.B.R.C and the amount of tax to pay, an issue analyzed from 1915 to 1936 since it strongly affected the City Hall budget (Mondaca, Segovia \& Sanchez, 2011).

For mining activity, the basic issues were the railway breach with the liabilities agreed on with nitrate companies, particularly Antofagasta Nitrate Co., the most important Chilean company in this line of business until 1907. Among complaints detailed by Isaac Arce, Pampa Alta administrator, in 1906 are: the towing machine service because its itinerary affected work; the negation to transport workers; the demand for loading wagons in the least possible time; the prohibition to use own cars in the railway; the transport of rails and crossbeams by the nitrate company; placing switches and habilitating by-ways; storage and wagon charges for transporting forage; and excess charges for transporting merchandise, materials, coal, and gunpowder (Archivo, 1906).

The placement of nitrate company rails in the central canton, which finally reached the railway, was hindered by the broad concession given to Milbourne Clark. Nevertheless, since 1887 attempts had been made to build railways independent of A.B.R.C, such as the one between Pampa Alta and San Pedro de Atacama in December 1887. In October 1893, Carlos A. Watters is allowed to build a railway, taking kilometer 20 of the current A.B.R.C. as a starting point. In August 1899, Enrique Barra made a request to build a steam engine railway from Chuquicamata copper mine to Antofagasta-Bolivia railway, being approved in December (Gonzalez-Pizarro, 2008). 
In general, the nitrate companies of the central canton had to operate with A.B.R.C. to export their production through Antofagasta port. Nitrate companies usually had private trains inside their premises, between nitrate concessions and supply yards, using locomotives and wagons. One of the most important companies, the Antofagasta Nitrate Co., was equipped with 41 80-250 h.p. steam engines; $890-150$ h.p. electric engines; $2506 \mathrm{~m}^{3}$ nitrate wagons; and $5401-2 \mathrm{~m}^{3}$ nitrate wagons, apart form 470 other wagons, all of which shows a panorama of the thriving activity in the desert (Gonzalez-Pizarro, 2003: 135).

The expansion of American capital, mainly Guggenheim Brothers', not only in Chuquicamata connected to Huanchaca Co. from 1899 until its shut-down -, but also in the powerful nitrate industry, when purchasing Anglo-Chilean Nitrate Company and Lautaro Nitrate Company in the 1920s and 1930s, led to a better planning between A.B.R.C. and the railway stations in the pampa and nitrate mines. Schedules allowed identifying railway stations and the type of railway machinery in use. In 1929, A.B.R.C. took charge of all the nitrate railways, committing to the conservation and repair of the existing ones. The railways became A.B.R.C. property and nitrate companies agreed on a monthly pay for each crossing and meters run.

A.B.R:C. and Chile North Railway established a new train service in 1929 (Thompson, 2003). Two mixed trains weekly covered the distance between Baquedano and El Toco and viceversa so as to give better service to nitrate mine inhabitants. The trains stopped in Baquedano to make connections with passenger trains travelling between Mejillones and Calama. In this way, passengers could arrive at Antofagasta at 3 p.m. In addition, passengers travelling to Baquedano sorroundings could make different combinations to move throughout the pampa and railway stations until arriving at Calama since a direct train to this city was available.

In the mid-1931, A.B.R.C changed the train schedule to Calama, affecting the itinerary of the train running downward, which was scheduled for Wednesday, Thursday, and Saturday. This made Lautaro Nitrate organize its own transport service for mail and workers' transport.

To have an impression of the railway service and how it connected different places in the nitrate pampa, let's take a look at the schedule in 1929:

\section{UPWARD TRIP}

Railway stations

\begin{tabular}{|c|c|c|}
\hline \multirow[b]{3}{*}{ Antofagasta } & \multicolumn{2}{|c|}{ Sunday \& Thursday } \\
\hline & Arrival & Departure \\
\hline & ---- & 9:35 \\
\hline Baquedano & -.-- & $13: 45$ \\
\hline La Rioja & 15:01 & $15: 05$ \\
\hline Deseada & 16:01 & $16: 20$ \\
\hline Los Dones & $16: 43$ & $17: 00$ \\
\hline Lynch & $17: 18$ & $17: 32$ \\
\hline $\begin{array}{l}\text { B. Astoreca y } \\
\text { Los Dones }\end{array}$ & 18:02 & 18:05 \\
\hline Miraje & $18: 29$ & $18: 40$ \\
\hline Chacance & 18:57 & $19: 10$ \\
\hline Toco & $20: 12$ & --- \\
\hline
\end{tabular}

Train 83

\begin{tabular}{|c|c|c|}
\hline & & $\begin{array}{l}\text { OWNWARD } \\
\text { TRIP }\end{array}$ \\
\hline & $\begin{array}{l}\text { Railway } \\
\text { Stations }\end{array}$ & Train 84 \\
\hline & $\mathrm{Mc}$ & \& Friday \\
\hline & Arrival & Departure \\
\hline Toco & ---- & 7:00 \\
\hline Chacance & $8: 02$ & $8: 07$ \\
\hline Miraje & $8: 26$ & $8: 31$ \\
\hline $\begin{array}{l}\text { B. Astoreca y } \\
\text { Los Dones }\end{array}$ & $8: 59$ & 9:01 \\
\hline Lynch & $9: 35$ & $9: 36$ \\
\hline Los Dones & $9: 48$ & $9: 56$ \\
\hline Deseada & $10: 15$ & $10: 20$ \\
\hline La Rioja & $11: 10$ & \\
\hline Baquedano & $12: 05$ & ---- \\
\hline Antofagasta & $15: 04$ & ---- \\
\hline
\end{tabular}


Changes made in May 1931 did not greatly affect schedules in the nitrate mines, but they highlighted the importance of Salinas railway station for mixed trains, both regular and special, and also the internacional train.

So, on Monday, the regular mixed train went up to Salinas at 1:15 p.m. and down to the same railway station at 11:15 a.m., following the usual itinerary; on Tuesday, the regular mixed train did not go up, but went down to the station at 11: 15 a.m.; while the international train went up at 1: 15 a.m., making connections between Salinas and Union stations; on Wednesday, the regular mixed train went up at 1:15 p.m. and did not go down, following the usual itinerary; the mixed train from Calama went down on this day and the international train went down, arriving at 6:20 p.m., making the connection above. On Thursday, there were no trains going up and down. On Friday, the regular mixed train did not go up, but 11:15-a.m. train went down, following the usual itinerary; the international train made a stop at Salinas at 11:15 a.m., making the usual connection. On Saturday, the regular mixed train went up at 1:15 p.m. and did not go down; the international train passed by Salinas at 6:20 p.m. On Sunday, only the regular mixed train ran, making a stop at Salinas at 1:15 p.m., when going up, and at 11:15 a.m., when going down (Archivo Historico, 1929).

International train trips from Antofagasta to Bolivia underwent difficulties when making a stop at Salinas station. Complaints included passengers' delay and change of second-class wagons from the mixed train arriving from Calama to add them to the international train. An service of "auto-gondolas" (small old buses) with a capacity of about 25 passengers from "María Elena" and "Chacabuco" nitrate mines was the only means for arriving at Salinas station.

The American administrators of Chuquicamata copper ore deposit signed an agreement with A.B.R.C. to use the railway for exporting the metal resource to international markets. The Chuquicamata train inaugurated in 1914 was connected to the main A.B.R.C. branch. The so-called Chuquicamata branch started from San Salvador station located to the north of Calama and arrived at Punta de Rieles, in a 10-km trip. In addition, A.B.R.C. built Conchi Viejo- El Abra branch in 1906 with a 19-km length to give service to the copper and silver exploitations existing to the north of Calama (Thomson-Angerstein, 1997; Castro 1984). The company profits depended on production levels which, in turn, depended on the copper pound quotation in the London stockmarket. However, Chile Exploration Company, the American company exploiting Chuquicamata mine, established The Chile Exploration Co. Railway to connect Chuquicamata and San Salvador, providing electricity in 1925. The first Chuquicamata general manager, Fred Hellman, built a railway inside the mine to transport materials and workers. It remained active until the appearance of big trucks in the early 1950s ( Monterrey, 2009).

In the 1970s, The Antofagasta and Bolivia Railway Co.Ltd. was involved in the difficulties affecting the Chilean politics and economics, until purchased by the Chilean entrepreneur with Croatian ancestors, Andronico Luksic, at the end of 1979 (Blakemore, 1996). In the 1980s, the frequency of the international train was once a week. At present, its acivities focus on commerce to and from Bolivia, along with CODELCO copper shipping. 


\section{Nitrate railways of El Toco, Aguas Blancas, and Taltal cantons: Private interests}

El Toco canton was located between parallels $21^{\circ}$ and $23^{\circ}$ and meridians $70^{\circ}$ and $69^{\circ}$, including 14 nitrate mines. It was the only canton using Shanks and Guggenheim systems since "Pedro de Valdivia" and "María Elena" nitrate mines were located in it, the latter being the last nitrate mine in operation.

Aguas Blancas canton was located between parallels $23^{\circ}$ and $24^{\circ}$ and meridians $70^{\circ}$ and $69^{\circ}$, including 22 nitrate mines.

Taltal canton, below parallel $25^{\circ}$ and between meridians $70^{\circ}$ and $69^{\circ}$, included 26 nitrate mines.

In the mid-1833, the English man, Edward Squire, built a railway in El Toco canton to connect El Toco nitrate mines with a port between Loa river and Cobija, as established by a law passed on January 23, 1888, which legalized this branch. The railway purchased by Anglo-Chilian Nitrate and Railway Co. Ltd. was inaugurated in 1890. Anglo-Chilian connected Jose Francisco Vergara nitrate mine in 1910. In 1927, this company was purchased by Guggenheim who could build branches to Pedro de Valdivia and María Elena nitrate mines. This led to the appearance of other stations between Maria Elena and Tocopilla: Tupiza, Cerrillos, Colupito, Central, Barriles, and Tigres. The Central station railway branched off to provide service to nitrate mines located to the SE: Maria Elena, J.F. Vergara, Coya up to Miraje station, and also to the NE to arrive at Ojeda, Puntillas, and El Toco stations, where it branched off again to include other nitrate mines.

Steam engines operated until 1958, being replaced by diesel engines. Their itinerary in the 1950s was scheduled on a weekly basis for passengers and cargo. This itinerary has the most curves and gradients, operating until today and owned by the Chile Chemical and Mining Society which, established in 1968 as a mixed company and then belonging to the State, is now in private hands.

The history of Taltal canton nitrate railway is related to the government decision in 1878 to make prospections for a railway connecting nitrate productive activity with the port. In 1880, the proposal presented by Alfredo Quaet- Faslem was accepted. He transferred his rights to Jorge Stevenson, who established Taltal Railway Company Ltd.,. Supported by John Meiggs, Stevenson could build the railway to Refresco in a short time. Between 1887 and 1928, the network enlarged, its shareholders making big profits. Canchas station railway branched off to the NW, in the direction of Santa Luisa and Alemania stations up to Lautaro. To the E, there was a group of five nitrate mines, Flor de Chile being the most notable, whose branch located in Ovalo station branched off again to the NW to connect Caupolican and Bascunan nitrate mines. After the 1930-1931 crisis, the company determined the destiny of the Shanks system nitrate mines, getting rid of, as Ian Thomson states, rolling stock in 1940, Taltal Railway Company Ltd. being sold to the Chilean company "Rumie \& Sons" in 1960. This company provided service to the last three nitrate mines. Alemania nitrate mine ended operations and the nitrate train was dismantled between 1977 and 1979 (Thomson, 2003). 
Coloso-Aguas Blancas railway history is one of the most intricate of the type. Since 1880, nitrate people had been asking the government the construction of a railway for Aguas Blancas nitrate mines and were fighting for an extension of what had been accepted for Juan Besterrica, Juan Vera, and Francisco Mirada to build the rails for a steam train between Antofagasta and Aguas Blancas (Rojas, 1883). In January 1884, the Congress discussed a railway from Antofagasta to Aguas Blancas since the previous one had been rejected. In 1896, Rafael Barazarte was given permission to build a railway between Paposo and Desierto ore deposit. In 1886, Arturo Prat Mining Co. and Taltal Railway Co. received the approval to build a railway between the port and the company's mining installations. On the next year, they were allowed to extend the railway to Cachinal. This issue was again dealt with in August 1889 by J. Phillips in order to build a steam railway between these two places. On September 1, 1897, approval was given to Jose Antonio Moreno to build and exploit a railway between Paposo and Desierto ore deposit (Gonzalez-Pizarro, 2008: 37-38). But the most relevant railway connecting Aguas Blancas nitrate mines was the one requested on November 28, 1898 by the firm "Granja \& Domínguez", which would build a railway between Antofagasta and Aguas Blancas. Permission was given a month later, the construction beginning in March 1899. Work done in 1900 showed that the firm was not using Antofagasta piers, but the habilitation of a site to the south of Antofagasta, a fact that revealed the firm strategy to avoid the opposition of the City Hall, boatmen unions, and A.B.R.C. On January 1, 1902, Coloso was ranked as a minor port. In March 1902, the railway connected "Pepita" nitrate mine with Coloso. Carrizo, La Negra, and Varillas stations were built between Coloso and Pepita. At Barazarte station, the branch to the east led to Yungay station with two branches including $90 \%$ of the canton nitrate mines. To the SE, it led to Rosario nitrate mine. The railway was open to the public for passenger transport. When Baltazar Dominguez died in 1902, his heirs sold the railway and nitrate belongings to Matias Granja. When this one died, Coloso-Aguas Blancas railway became involved in one of the most commented scandals of the time, mixing business and politics, which in turn involved the government at that time - 1907. This is what some authors have called "the famous affair of Granja house" (Recabarren, Obilinovic, Panades, 1989: 61-67). Finally, the transfer of the railway from Granja to W.R. Grace in 1908 ended in the railway being in the hands of The Antofagasta (Chili) and Bolivia Railway Company Ltd. It was 1909. In this way, all the private railways in the province were in the hands of English A.B.R.C. capitals. The train continued operations as long as nitrate mines working with the Shanks system could be profitable. In 1932, some branches were dismantled and it definitely disappeared in 1961.

In the nitrate pampa, the mines operating with private trains ruled railway jobs. Each nitrate mine had a Traffic Chief in charge of keeping the rails in good state and do necessary repairs. He was the direct boss of the engine driver, whose main job was to keep the boiler water at the right level and check the good state of all the engine keys and valves; firemen, dedicated to keep the engine throroughly clean, manage fire, and burn the coal or oil; and lastly, brakemen, in charge of taking care of the brakes of the train in motion. Railroad workers worked in the rails. There were also the so-called engine starters in charge of the lamps of trains in motion and lighting the engine fire at dawn. ( Macuer, 1930: 170-172; Gonzalez-Pizarro, 2003:312-314). 


\section{The Noth longitudinal railway: The state intervention}

The construction of the North Longitudinal Railway started when the government decided to extend the fiscal railway from Pueblo Hundido, in Copiapo province, to Pintados, in Tarapaca. Reasons of national safety and territory integration lay behind this venture. A public bid, after some failures, was awarded to Chilian Northern Railway Co. Ltd in 1910.

The well-known North Longitudinal, the famous Longino, was finally inaugurated on January 10, 1919 (Thomson, 2003), although the definite exploitation of de journey between Iquique and Calera started on March 19, 1930 (En Viaje, 1960: № 325).

The North Longitudinal was connected to Santiago and Valparaíso trains. It included several stations, starting in Pueblo Hundido, followed by Altamira, Catalina, Balmaceda, Los Vientos, Lacalle, Agua Buena, Aguas Blancas, Oriente, Palestina, Desierto, Baquedano, (to Antofagasta and Calama), Rioja, Deseada, Los Dones, Lynch, Miraje, Chacabuco, El Toco, Santa Fe, and Quillagua. In 1966, the trip from Calera to Iquique was scheduled for Sunday (with a connection to and from Antofagasta) using first-class, second-class, and buffet wagons, the latter being the most complete; on Thursday, there was a trip from Baquedano to Calama, with second-class and buffet wagons; on Saturday, the train arrived at Antofagasta, with the same wagons as on Thursday; on Tuesday, there was a train with second-class and buffet wagons arriving at El Toco. The trip from Iquique to Calera was scheduled for Monday and Thursday; the trip from Antofagasta to El Toco, Tuesday and Saturday (En Viaje, 1966: N³88)

Unlike what happened to A.B.R.C., which would later add Chuquicamata copper mining production to its load transported to Antofagasta, the North Longitudinal had to overcome economic difficulties in time. Ian Thomson, the English railway specialist, only slightly states the adverse picture of the Longitudinal crossing the desert: "A longitudinal railway to travel along one of the world's most arid zones had been built; (i) where agricultural production is practically none; (ii) where population is non-existing, except for a very limited number of small cities; (iii) where mining production is also scarce, and; (iv) which would have very limited expectations to make long journeys to and from the country's central and south zones" (Thomson, 2003:48). In the 1950s, its material had not been replaced and maintainance costs were high. The accelerated disappearance of Shanks system nitrate mines involved passenger and cargo loss. Only in the mid-1950s, the State Railway Co. considered connecting appealing desert locations to its tourist agenda. It was the beginning of a tourist massification boom in the Chilean north, supported by the railway as a non-elitist popular means of transport, as experimented in the U.S.A. (Sheffer, 2001). This happening helped discovering the northern geography as a tourist landscape, together with a State policy to support northern cities. In 1934, the State Railway Co. started publishing a Tourist Guide which did not strongly stimulated visits to northern "tourist" attractions, but those in the south. Nevertheless, another State Railway Co. publication, En Viaje, included places located in the preandean locations and the city of Antofagasta in its pages in the late 1940s. Paradoxically, the North Logitudinal did not arrive at these places (except the city of Antofagasta, where A.B.R.C. had built a railway branch between Baquedano and the port, based on an agreement with The Chilian Northern in 1921). In this way, the main cities could be known and a "leisure and winter tourism" could be institutionalized in the northern zone, where the railway and roads made recreation possible (Gonzalez-Pizarro, Ms). 
The North Longitudinal Railway administration was transferred to A.B.R.C. in 1919 under the name Chilian Northern, a situation that remained until October 1957, when the government decided to transfer Chilian Northern to the State Railway Co., authorizing A.B.R.C. to administrate it until May 1961. The most popular Atacama dersert train operated until June 9, 1975.

The northern novelist Hernan Rivera-Letelier would strongly evoque the famous Longino in his work Trains go to Purgatory.

\section{The Antofagasta-salta railway: From citizen initiative to bi-state concretion}

One of the railways having the greatest support by citizens, after Antofagasta-Salinas and Caracoles, was the Antofagasta-Salta railway.

In November 1966, En Viaje magazine director, Manuel Jofre, wrote that this venture had started in Argentina, by naming a study commission, but it soon found opposition on both sides because "some sectors considered that it was against the interest of farmers in the south of both Chile and Argentina. For this reason, the project was delayed" (Jofre, 1966:17).

It was precisely the A.B.R.C. - The Antofagasta and Bolivia Railway Co. Ltd - which made the first studies in 1888 to connect the Argentinian northeast with the Chilean north, through a group of engineers. One of them, Luis Abd- El Kader, with Italian-Arab ancestors, was greatly influencial in the urban planning of Antofagasta, where, as Thomson \& Angerstein state, a connection with Argentina Grand Central Railway would be looked for with a design starting from Sierra Gorda station, going through Caracoles mine, San Pedro de Atacama, and Aguas Calientes and then arriving at the Argentinian territory through Huaytiquina. These authors conclude that this study had great advantages, a steady income from local transport because the railway crossed an area very rich in minerals, among others (Thomson- Angerstein, 1997: 172-173). The project did not succeed probably owing to the territory dispute, solved in 1899, of the Atacama puna between Chile and Argentina.

A new impulse to this venture came from the coincidence between Mejillones re-foundation efforts made by the government and A.B.R.C. request for land to install its machine shop bewteen 1904 and 1906, on the one hand, and the Argentinian renewed effort made by engineer Manuel Sola who, in 1905, called the government attention to the huge advantages Mejillones offered to export the agricultural and cattle production from Salta and the new Andes territory through its port. According to Sola, "All the input for men and animal survival easily find a market in this province. Cattle is imported from Salta (Argentinian Republic) and the south of Chile; flower, from California; rice, sugar, and fruits, from Peru; tobacco, from La Habana and Bolivia; wine, beer, cereals, beans, vegetables, barley, dry grass, and another hundred products from the south of Chile" (Solá, 1906:19). Sola's ideas were supported by other Argentinian reports such as Dr. Arturo S. Torino's in 1906 and exposed to the Argentinian Congress by the Minister of Foreign Affairs at that time, Estanislao Zeballos. On the following year, July 1907, Horacio Fabres, Manuel Maira, and Santiago Zanelli requested the government authorization to build a transandean railway to connect Mejillones and Salta. After putting it off several times, the railway was inaugurated in June 1911(Sociedad Nacional de Agricultura, 1922: 5-6). 
But there was also another issue in this connectivity: the Chilean government authorization for the construction of a new Antofagasta port based on Law $N^{\circ} 2390$, passed on September 7, 1910, which was fruitful in 1913 when the Port Commission reported the connectivity Antofagasta natural attraction zone - of the Mejillones-Salta projected railway, which should take advantage of the new installations in the future (Gonzalez-Pizarro, 2010 a).

This proposal was supported by citizens - laborers' unions, political parties, and commercial and industrial associations -; disseminated in Open City Hall Meetings; and also supported by the establishment of the Salta Pro-Railway Executive Commission. Since April 5, 1920, multitudinal meetings in the form of Open City Hall Meetings were organized in favor of the proposal. For mayor Maximiliano Poblete-Cortes, the railway was of "national conveniente because it will help in the development of one of the country's most important regions; it will attract a big part of Argentinian commerce to the Pacific; and, therefore, there will be an increase in freight and cargo for our merchant marine; some of our industries, such as the nitrate one, will increase their production to fertilize land producing sugar cane, cotton, etc. Other industries such as shoe-making, canned food, and maybe other ones will have a safe market. Concerning regional coexistence, we believe no one can deny it. At present, the life and progress of Antofagasta and the whole region are closely related to the development and prosperity of nitrate and copper industries (Gonzalez-Pizarro, 1994, 1995, 1999, 2002).

The same response was given by Argentina, where a Pro-Pacific Railway Commission was established in 1921, its director being Luis de los Rios. This commission organized "various acts that gave prestige and widely disseminated Salta population's mood". The railway construction also lead to a geopolitical mistrust view from the military prism, while in Antofagasta, civilians reaffirmed their conviction of the integration with the Argentinian northeast" (Benedeti, 2005).

Government actions from both sides led to the investment budget agenda agreed on by the Chilean Minister of Foreign Affairs, Ernesto Barros Jarpa, and the Argentinian Envoy Extraordinary and Minister Plenipotentiary in Chile, Carlos M. Noel, on April 25, 1922. The project, however, could only be improved in 1928. In 1930, Argentina had already built the railway from Salta to San Antonio de los Cobres. Finally, the railway was constructed in Augusta Victoria station sector in 1937, after recovering from the 1930-1932 world crisis (Thomson, 2003, 2006).

During the early 1940s, the government increased its contribution to speed up the railway construction. Curiously enough, as stated by Alejandro Benedetti, the railway that had been thought of by Argentina to improve the Andes Territory would arrive late, when the territory had disappeared in 1943 to favor Salta, Jujuy, and Tucuman provinces. This was a bad sign. The Chilean north still cherished hopes for the railway, months before being inaugurated because, apart from the work of many people, "the cost of living in the northern provinces will be cheaper... it will avoid the current supply difficulties and complications due to the scarcity of cargo ships... The railway does not only have an economic mission, but it also takes the torch of progress, culture, mutual knowledge and, therefore, people's physical and spiritual welfare everywhere" (Szigethy, 1948: 67-68).

On February 20, 1948, the President of Argentina, Juan D. Peron, inaugurated the railway in the Argentinian sector, with the presence of Antofagasta Mayor, Juan de Dios Carmona. 
In 1949, the Antofagasta-Salta railway was scheduled on a weekly basis, the journey taking two days: the train included regular and buffet wagons. It started from Antofagasta on Sunday and arrived at Salta on Tuesday.

Nevertheless, high transport costs, exceeded by truck competente in time, did not meet the expectations of both regions. A.B.R.C. operated the railway, as contrated with the government in the 1920s, and as stated by Ian Thomson, assigned "old engines left over from other operations to cargo trains (and) in the mid-1950s, assigned relatively modern steam engines for passengers' service" (Thomson, 2006: 145) until 1964. In the 1960s, the State Railway Co. started operations on the rails. At the end of 1970, passengers' trips were cancelled. In 1990, it was transferred to Ferronor S.A., a Production-Fostering Corporation (CORFO, for its acronym in Spanish) company, privatized in 1996. At present, the railway operates only sporadically.

\section{References}

Ahumada, María T. 1999. El Establecimiento Industrial de Playa Blanca en Antofagasta. Antofagasta: Ediciones Santos Ossa.

Anguita, Ricardo. 1912. Leyes promulgadas en Chile desde 1810 hasta el $1^{\circ}$ de junio de 1913. Santiago de Chile: Imprenta, Litografía i Encuadernación Barcelona, Tomo III.

Aramayo, Cesáreo. 1959. Ferrocarriles bolivianos. Pasado, presente y futuro. La Paz: Imprenta Nacional.

Arce, Isaac. 1930. Narraciones Históricas de Antofagasta. Antofagasta: Imprenta Moderna.

Archivo Escuela de Derecho, Universidad Católica del Norte. 1906. Archivo de Isaac Arce. Carpeta varia "Personal y Salitrera".

Archivo historico, Universidad Católica del Norte. 1929. Archivo Salitrero Oficina Chacabuco: Caja "Medios de Transporte. Años 1920-1939.Transporte y Comunicaciones". Circular de la Administración del F.C.A.B, Antofagasta, 29 de mayo de 1929.

Benedetti, Alejandro. 2005. "El ferrocarril Huaytiquina, entre el progreso y el fracaso. Aproximaciones desde la geografía histórica del territorio de los Andes", Revista Escuela de Historia, Salta, enero-diciembre, $N^{\circ}$ 4, 123-165. Disponible en http:/ / wwwscielo.org.ar/scielo.php?script=sci_arttext\&pid=S1669-

90412005000100007\&ing=es\&nrm=iso. Consulta el 14 de agosto de 2011.

Bertrand, Alejandro. 1885. Memoria sobre las cordilleras del desierto de Atacama i rejiones limítrofes. Santiago de Chile: Imprenta Nacional.

Blakemore, Harold. 1991. “ ¿Nacionalismo frustrado? Chile y el salitre, 1870-1895” en Harold Blakemore, Dos estudios sobre salitre y política en Chile (1870-1895). Editado por Luis Ortega. Santiago de Chile. Departamento de Historia. Universidad de Santiago de Chile.

Blakemore, Harold.1996. Historia del Ferrocarril de Antofagasta a Bolivia 1888-1988. Traducción de Juan Ricardo Couyoumdjian y Beatríz Kase. Santiago de Chile: Impresos Universitarios S.A.

Bowman, Isaiah. 1924. Desert Trails of Atacama. New York: American Geographical Society.

Braudel, Fernando, 1970. La historia y las ciencias sociales. Madrid: Alianza Editorial.

Bravo Quezada, Carmen G. 2000. La Flor del Desierto. El mineral de Caracoles y su impacto en la economía chilena. Santiago de Chile: Dibam, Lom Ediciones, Centro de Investigaciones Diego Barros Arana.

Bresson, André. 1997 [1886]. Una visión francesa del Litoral Boliviano (1886). La Paz: Stampa Grafica Digital. 
Calderón G. Fernando, Coordinador. 2003. Formación y evolución del espacio nacional. La Paz: Ed.Ceres.

Castro, Marina T. 1984. F.C.A.B. Una ruta de Nostalgias. Antofagasta: s.p.i.

En Viaje, 1960. "Ferrocarriles vencedores del desierto y la montaña". Santiago: noviembre, Número 325

En Viaje, 1966. "Valores de pasajes sencillos en trenes expresos, ordinarios y mixtos, entre las principales estaciones de Santiago a Calera, Iquique y ramales". Santiago: febrero, Número 388.

Jofré N. Manuel. 1966. “Antofagasta: terminal FF.CC. Internacionales", Revista En Viaje, noviembre, Número 397.

Gómez Zubiela, Luis R. 1999. Ferrocarriles en Bolivia. Del anhelo a la frustración 1860-1925. Tesis de Licenciatura en Historia. Universidad Mayor de San Andrés, La Paz. Una versión en Políticas de Transporte Ferroviario en Bolivia 1860-1940. Disponible en www.boliviaenlared.gm/.../politica-transporte-ferroviario-bolivia.pdf. Consulta 19 de agosto 2011.

Gonzalez Pizarro, José A. 1994. “El FF.CC. de Antofagasta a Salta: Regionalización e Integración", Actas del II Seminario Internacional de Integración Subregional, Universidad Nacional de Jujuy-Universidad Católica de Salta.

Gonzalez Pizarro, José A. 1995. “La expresión regionalista en Antofagasta: base social, demanda comercial y canalización política. El FF.CC. de Antofagasta a Salta en 1920-1930" Primer Encuentro de Historia Económica y Social, Universidad de Santiago de Chile.

Gonzalez Pizarro, José A. 1999. “El ferrocarril que dio vida a la región” y “El desarrollo de la complementación económica" en Noa-Norte Grande. Crónica de dos regiones integradas. Buenos Aires: Embajada de Chile en Argentina, pp. 87-93-150-154.

Gonzalez Pizarro, José A. 2002. "Espacio y política en Antofagasta en el ciclo salitrero. La percepción del desierto y el sentimiento regionalista, 1880-1930" en Viviana ContiMarcelo Lagos, Compiladores, Una Tierra y tres naciones. El litoral salitrero entre 1830 y 1930. Jujuy: Universidad Nacional. Unidad de Investigación en Historia Regional, pp. 251-290.

Gonzalez Pizarro, José A. 2003. La pampa salitrera en Antofagasta. La vida cotidiana durante los ciclos Shanks y Guggenheim en el desierto de Atacama. Antofagasta: Corporación Pro Antofagasta.

Gonzalez Pizarro, José A. 2005. “Chile y Bolivia (1810-2000)” en LACOSTE, P. (Compilador) Argentina - Chile y sus vecinos. Mendoza: Editorial Caviar Bleu. Colección Cono Sur, Tomo I, pp. 335-392.

Gonzalez Pizarro, José A. 2008. “Conquering a natural boundary. Mentalities and technologies in the communication paths of the Atacama desert", Revista de Geografía Norte Grande, Pontificia Universidad Católica de Chile, Número 40, septiembre, pp. 23-46.

Gonzalez Pizarro, José A. 2008 a “'La emigración boliviana en la precordillera de la región de Antofagasta: 1910-1930. Redes sociales y estudio de casos", Revista de Ciencias Sociales, Iquique, Número 21, pp. 61-85.

Gonzalez Pizarro, José A. 2009. "Contrasting Imaginaries: The Atacama Desert perceived from the Region and Observed from the Nation", Revista de Dialectología y Tradiciones Populares. Antropología. Etnografía. Folklore. Madrid, Vol. LXIV, N 2, Julio-diciembre, pp. 91-116. 
Gonzalez Pizarro, José A. 2009a. “The province of Antofagasta. Creation and consolidation of a new territory in Chile: 1888-1933", Revista de Indias. Madrid, Vol. LXX, N²49, mayo-agosto, pp. 345-380.

Gonzalez Pizarro, José A. 2009b. “La huelga/masacre de la Plaza Colón: 6 de febrero de 1906 en Antofagasta. Las lecciones para la historia" en Pablo Artaza, Sergio González Miranda, Susana Jiles Castillo (Editores), A cien años de la masacre de Santa María de Iquique. Santiago: Lom Ediciones, pp. 211-239.

Gonzalez Pizarro, José A. 2010. “La influencia de la legislación municipal boliviana en Antofagasta, 1879-1888. Un capítulo desconocido en la historia del derecho público chileno", en Estudios en Honor de Bernardino Bravo Lira, Premio Nacional de Historia. 2010. Revista Chilena de Historia del Derecho, Facultad de Derecho de la Universidad de Chile, Número 22, Tomo II, 913-937.

Gonzalez Pizarro, José A. 2010a. "El Puerto Fiscal y la ciudad de Antofagasta" en Liliana Cordero Vitaglic, Coordinación y Edición, Historia Gráfica del Puerto de Antofagasta. Abril 1919-Agosto 1929. Antofagasta: Universidad Católica del NorteGobierno de Chile, Gobierno Regional de Antofagasta- Consejo Regional- Consejo Nacional de la Cultura y las Artes, Impresión Graficandes, pp. 9-27

Gonzalez Pizarro, José A. Ms. Geografía del desierto y turismo de la naturaleza. La revista En Viaje y la mirada sobre el paisaje nortino: 1945-1966. En Revista de Geografía Norte Grande, Pontificia Universidad Católica de Chile, aceptado y a publicarse en el número 52, septiembre de 2012.

Greve, Ernesto. 1944. Historia de la Ingeniería en Chile. Santiago de Chile: Imprenta Universitaria, Tomo III.

Informe Económico Ferrocarril de Antofagasta a Bolivia. 1959. The Bolivia Railway Company. Anexo. Un comentario del Dr. Humberto Fossati. Oruro: Universidad Técnica de Oruro. Departamento de Extensión Cultural.

Lagos C. Guillermo, 1981. Historia de la frontera de Chile. Los tratados de límites con Bolivia. Santiago de Chile: Editorial Andrés Bello.

Macuer Llaña, Horacio. 1930. Manual Práctico de los trabajos en la Pampa Salitrera. Valparaíso: Talleres Gráficos Salesianos.

Mandiola, Juan-Castillo, Pedro. 1894. Guía de Antofagasta. Antofagasta: Imprenta El Industrial.

Mendieta Parada, Pilar. 2006. “Oruro: ciudad moderna y cosmopolita 1892-1930” en Ximena Medinacelli, Coordinación, Ensayos Históricos sobre Oruro. La Paz: Sierpe Publicaciones.

Mitre, Antonio. 1981. Los Patriarcas de la Plata. Estructura socioeconómica de la minería boliviana en el siglo XIX. Lima: Instituto de Estudios Peruanos.

Mondaca R. Carlos- Segovia B. Wilson-Sánchez G. Elizabeth. 2011. Historia y Sociedad del Departamento del Loa. Calama, una mirada desde los archivos. El municipio y la construcción social del espacio 1879-1950. Calama: Orizonta Producciones Digitales.

Monterrey C. Nancy. 2009. Chuquicamata. Otras voces te recuerdan. Antofagasta: Sergraf Ltda.

Nuñez Atencio, Lautaro.1992. Cultura y conflicto en los oasis de San Pedro de Atacama. Santiago de Chile: Editorial Universitaria.

Panades, Juan. 1990. "La maestranza del Ferrocarril Antofagasta a Bolivia en Mejillones”. Anexo I. En Julio Pinto Vallejos- Luis Ortega Martínez, Expansión minera y desarrollo industrial: un caso de crecimiento asociado (Chile 1850-1914). Santiago de Chile: Universidad de Santiago de Chile, pp. 113-136.

Pérez, Alexis. 1997. "El intercambio comercial Bolivia-Chile y el tratado de límites de 1874" en Rossana Barragán, Dora Cajías, Seemin Qayam, Compiladoras, El Siglo XIX. 
Bolivia y América Latina. La Paz: IFEA-Embajada de Francia- Coordinadora de Historia, Muela del Diablo Editores.

Philippi, Rodulfo .A. 2008 [1860]. Viaje al desierto de Atacama. Estudio Preliminar de Augusto Bruna-Andrea Larroucau. Santiago de Chile: Biblioteca Fundamentos de la Construcción de Chile (Facultad de Historia, Geografía y Ciencia Política, Pontificia Universidad Católica de Chile-Fundación RA Philippi de Estudios NaturalesBiblioteca Nacional de Chile- Cámara Chilena de la Construcción), Tomo 39.

Ramirez N. Hernán. 2007. Balmaceda y la contrarrevolución de 1891. En Hernán Ramírez Necochea, Obras Escogidas. Selección, edición y estudio preliminar Julio Pinto. Santiago de Chile: Lom Ediciones- Consejo Nacional de la Cultura y las Artes.

Recabarren R. Floreal. 2002. Episodios de la vida regional. Antofagasta: Corporación Pro Antofagasta- Universidad Católica del Norte.

Recabarren R. Floreal-Obilinovic A. Antonio-Panades V. Juan. 1989 [ 1983 1 Ed).Coloso. Una aventura histórica. Antofagasta: Imprenta Atelier.

Rojas D. Matías. 1883. El Desierto de Atacama i el Territorio Reivindicado. Antofagasta: Imprenta de El Industrial.

Sagredo Baeza, Rafael. 2001. La gira del presidente Balmaceda al norte. El inicio del "crudo y riguroso invierno de su quinquenio", (verano de 1889). Santiago de Chile: Lom Ediciones-Universidad Arturo Prat- Centro de Investigaciones Diego Barros Arana.

San Roman, Francisco. J. 1896. Desierto y Cordilleras de Atacama. Santiago de Chile: Imprenta Nacional. 2 tomos.

Sheffer, M. 2001. See America First. Tourism and National Identity, 1880-1940. Washington: Laborersonian Institute Press.

Sociedad Nacional De Agricultura, 1922. Ferrocarril trasandino de Antofagasta a Salta. Santiago de Chile: s.p.i.

Solá, Manuel. 1906. Ferrocarril Trasandino de Salta a Mejillones o Antofagasta. Salta: Imprenta y Tipografía El Cívico.

Szigethy, Teodoro de. 1948. "El Ferrocarril de Salta a Antofagasta y su importancia", Revista En Viaje, febrero, Número 172, pp. 66-68.

Thompson, Ian. 2003. Red Norte: La historia de los ferrocarriles del norte chileno. Santiago de Chile: Publicación patrocinada por el Instituto de Ingenieros de Chile, Imprenta Silva.

Thomson, Ian Thomson. 2006. "Los ferrocarriles del Capricornio Andino", en Angel Cabezas, María Isabel Hernández, Lautaro Núñez, Mario Vásquez, Comité Editor, Las Rutas del Capricornio Andino. Huellas milenarias de Antofagasta, San Pedro de Atacama, Jujuy y Salta. Santiago de Chile: Consejo de Monumentos Nacionales, Santiago de Chile, pp. 137-149.

Thomson, Ian- Angerstein, Dietrich. 1997. Historia del ferrocarril en Chile. Santiago: DibamCentro de Investigaciones Diego Barros Arana. 


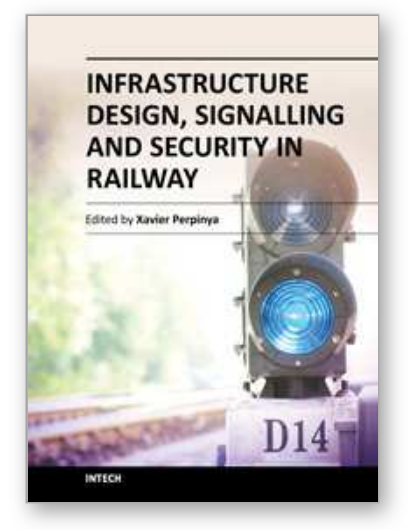

\author{
Infrastructure Design, Signalling and Security in Railway \\ Edited by Dr. Xavier Perpinya
}

ISBN 978-953-51-0448-3

Hard cover, 522 pages

Publisher InTech

Published online 04, April, 2012

Published in print edition April, 2012

Railway transportation has become one of the main technological advances of our society. Since the first railway used to carry coal from a mine in Shropshire (England, 1600), a lot of efforts have been made to improve this transportation concept. One of its milestones was the invention and development of the steam locomotive, but commercial rail travels became practical two hundred years later. From these first attempts, railway infrastructures, signalling and security have evolved and become more complex than those performed in its earlier stages. This book will provide readers a comprehensive technical guide, covering these topics and presenting a brief overview of selected railway systems in the world. The objective of the book is to serve as a valuable reference for students, educators, scientists, faculty members, researchers, and engineers.

\title{
How to reference
}

In order to correctly reference this scholarly work, feel free to copy and paste the following:

Jose Antonio Gonzalez-Pizarro (2012). Privatization Versus Public Funding on the Atacama Desert Railway An Interpretation, Infrastructure Design, Signalling and Security in Railway, Dr. Xavier Perpinya (Ed.), ISBN: 978-953-51-0448-3, InTech, Available from: http://www.intechopen.com/books/infrastructure-design-signallingand-security-in-railway/privatization-versus-public-funding-on-the-atacama-desert-railway

\section{INTECH}

open science | open minds

\section{InTech Europe}

University Campus STeP Ri

Slavka Krautzeka 83/A

51000 Rijeka, Croatia

Phone: +385 (51) 770447

Fax: +385 (51) 686166

www.intechopen.com

\section{InTech China}

Unit 405, Office Block, Hotel Equatorial Shanghai

No.65, Yan An Road (West), Shanghai, 200040, China

中国上海市延安西路65号上海国际贵都大饭店办公楼 405 单元

Phone: +86-21-62489820

Fax: +86-21-62489821 
(C) 2012 The Author(s). Licensee IntechOpen. This is an open access article distributed under the terms of the Creative Commons Attribution 3.0 License, which permits unrestricted use, distribution, and reproduction in any medium, provided the original work is properly cited. 